\title{
METACOGNITIVE STRATEGY AND STUDENT'S READING COMPREHENSION: AN EXPERIMENTAL STUDY AT SMK N 1 KOTA BENGKULU
}

\author{
Herlina Syafrianti \\ Universitas Bengkulu \\ linafatra03@gmail.com \\ Bambang Suwarno \\ Universitas Bengkulu \\ wdsaraswati@gmail.com \\ Elfrida \\ Universitas Bengkulu \\ mrs.elfrida@gmail.com
}

\begin{abstract}
This research aimed to know the effect of using metacognitive strategy towards student's reading comprehension. The design was quasi-experimental. The sample consists of 69 students in two classes. The instrument consists of reading test which was tried out. The treatment for the experiment group was metacognitive strategy and for the control group was the strategy that the teacher use in the class. The data were collected through pre-test and post-test. The activity in the classroom during six meetings, two meetings for pre-test and post-test and four meetings for teaching in the classroom. The data was analyzed by The Wilcoxon Test and The Mann-Whitney Test. The Wilcoxon Test for the control group showed that there was no significant difference between pre-test and post-test. The Wilcoxon test for the experiment group showed that there was significant difference between pre-test and post-test. The Mann-Whitney test for pre-test showed that there was no significant difference between experiment and control class. The Mann-Whitney test for post-test showed that there was significant difference between experiment and control class. Finding of the research showed that, there was significant difference between pre-test and post-test for the experiment class and there was significant differece between experiment and control class for post-test result. This result indicated that there was an effect of metacognitive strategy towards student's reading comprehension.
\end{abstract}

Key words: Metacognitive Strategy, Student's Reading Comprehension, TEFL.

\section{INTRODUCTION}

A language has four basic skills that has to be mastered by language learners because those skills are important to be developed by the students. They are listening, speaking, reading and writing skills. Reading is one of the critical skills to improve students'basic language skills. The students are expected to acquire deep understanding and comprehension about the language. Such things will help students to build their other abilities because having good reading comprehension means that students know the vocabulary, grammar, and message conveyed. It is in accordancewith what was stated by Hamra and Syatriana (2010) that the key to improve learning outcome in many fields of study is reading. It is a necessary skill for foreign 
language students which should be mastered. One of the duties of students is to comprehend many kinds of text. It is relevant to the purpose of reading which is to get information by constructing their creative thinking and combining to prior knowledge, previous experience, situation and idea.

Sutarji (2016) stated reading is an important social role in human life of all time which used by the reader to get information which delivered by the writer through words and written.According to Hamra and Syatriana (2010), many study results indicated that Indonesia students could master English language. Mastering English means that the students can develop their knowledge in the learning mateial and communicate with other people from other countries.

Students in these cases were notonly from the level of elementary schools but also fromjunior high schools, senior high schools and universities. The researcher experienced that phenomenon in teaching and learning process in Information Computer Technique (TKI) SMKN 1 Bengkulu City. This program consisted of four classes in first semester. The classes mostly consisted of malestudents, therefore teacher often found it difficult to convey the information or materials because the students could not comprehend the materialsthe teacher taught. The awareness of students in reading skillwas low. In this case, the researcher thinks that the students have to find the strategies that are suitable for them in teaching and learning process.

Learning strategies are the factors that play important part in the learning process. It can be used to find out the good ways to learn a language. Besides, learning strategy will also strengthen leaner's mental and behavioral activities which have strong influence in learning process. The learners who apply learning strategy may control some conditions of their learning process such as easy learning, maintaining knowledge, and using knowledge appropriately.

The use of appropriate strategy can improve efficiency and effectiveness in teaching. However, based on real life situation, it was found teaching techniques applied by teachers were less varied.Most teachers still applied teacher-centered learning strategy. Teachers could not yet exploit the ability of students to the maximum. This matter can lead to students tendency to be passive and less aroused tothink creatively. In addition, low understanding of students can be caused by studentsunawareness of how they learn. This can result to students'low awareness in achieving the learning objectives.

The learning process should be able to deliver an opportunity for students to construct their own knowledge conscious and students must be mentally active construct their knowledge based on the cognitive maturity it has. In this case, lessonsstrategy applied by teachers are unable to raisestudents' awareness in managing the thinking process of students. Metacognitive strategies refer to ways to raise awareness of the thinking process and the prevailing learning so that when this consciousness manifests, thenone can guard his mind by designing, monitoring and judging what he learned.

In the process of learning the students can apply learning strategies. The suitable strategies will help them in learning language. One of the strategies that the researcher focuses on is metacognitive strategy. The term metacognitive is important under the scope of learning. According to Richards and Schmidt (2002), metacognitive is management to mental process will help 
the learner to control their own learning activities. Learners with metacognitive knowledge will recognize which kind of learning tasks that cause difficulty, which approach that is better to remember information, and how to solve different kinds of problems. Applying this metacognitive strategy will help the students to learn better because they have organized what they have to do.

Learners with good metacogntive strategy have good potential because they can control their mind and cognitive process actively in learning process. Peters (2000) states that metacognitive strategy makes it possible for students to grow up as independent students because they can manage their own self and minds.

There are some researches and journals about the relationship between metacognitive strategy and reading comprehension. Hidayat (2015) found that there was a positive correlation between metacognitive strategy and reading ability in class VII of Junior High School. Another researcher, Tavakoli (2014) showed that there was a strong positive correlation between reported metacognitive awareness of reading strategies and reading comprehension achievement. Rastegar et.al (2017) revealed that there was a significant positie relationship between the use of overall metacognitive reading strategies by the participants and their reading comprehension achievement. In short, researches above showed that there was a correlation between two variables which were metacognitive strategy and reading comprehension.

Due to the facts above, the researcher is interested in applying this strategy since metacognitive strategy has a good relationship with reading comprehension or reading achievement.
This research was conducted in order to find out whether or not there is any effect of using metacognitive strategy towards student's reading comprehension. So far, this research has not been conducted yet in Bengkulu.

However, there has not been a similar study in Vocational High Schools in Bengkulu. Moreover, there has not been a similar research conducted by English education students in university level. Therefore, the researcher proposed to conduct such study at SMKN 1 Kota Bengkulu. SMKN 1 is the best Vocational High School in Bengkulu with many achievements in many events of arts, science, and sports. The researcher had a data checking in Department Education and Cultural Bengkulu Province about the average score of National Exam (UN) gained by this school. The data showed that this school gained the best score for level of Vocational High School in Bengkulu Province. Due to that fact, the researcher chose this school as the subject of this research and the title of the research is "Metacognitive Strategy and Student's Reading Comprehension: An Experimental Study of SMK N 1 Kota Bengkulu".

\section{METHOD}

This study was conducted by usingexperimental design.According to Nunan (1992), experimental design is a step for investigating and testing hypothesis between variables can be tested. On the other hand, Kothari (2004) remarks experiment is the process of examining the truth of statistical that related to research problem and hypotheses. This study used quasi experimental design. In addition, Creswell (2012) said that quasi experiment is the development design from true experimental design which the variable 
cannot be randomly assigned.It because the interaction of variable and other factors.

There were two variables of this study which were students' reading comprehension and metacognitive strategy. Students' reading comprehension was dependent variable, whereasmetacognitive strategy was independent variable.In achieving objectives of the study, pre-test and posttest were applied in class to gain the data as instrument by using t-test. In this study, there were two groups of class : experiment class and control class.

The experiment was carried out in 6 meetings. The treatment was applied 4 timesto each class by using short tex.Pretest was conducted in the first meeting whereas post-test was conducted at the end of meeting.

This study was conducted at TKI (Information and Computer Technique) Program of SMKN 1 Kota Bengkulu. It is located at Jati Street No.41 Sawah Lebar, Bengkulu City. The study started from October $24^{\text {th }}$ until November $27^{\text {th }} 2017$. The population of this study consisted of four classes (first semester) in TKI (Information and Computer Technique) Program of SMKN 1 Kota Bengkulu with teaching period $2017 / 2018$. The sampling technique of this study was purposive sampling. Purposive sampling is a technique of determining samples with certain considerations (Sugiyono, 2016). This purposive sampling technique is used by choosing two average classes which did not significantly differ from each other in terms of students' ability.

There were some sections to be implemented before collecting the data. English test was the instrument of this research. The tests used were pre-test and post-test. Pre-test was administered to determine student's beginning knowledge before they were given the treatment and the data of pre-test was compared with data of post-test later on. After treatment, the researcher gave posttest to the students for measured on some attribute that was assessed for students in experiment.

Table 1The Population of the

Research

\begin{tabular}{|c|c|c|}
\hline No & Class & $\begin{array}{c}\text { Total Number Of The } \\
\text { Students }\end{array}$ \\
\hline 1. & X TKI 1 & 34 \\
\hline 2. & X TKI 2 & 35 \\
\hline 3. & X TKI 3 & 30 \\
\hline 4. & X TKI 4 & 29 \\
\hline \multicolumn{3}{|c|}{ Total121 } \\
\hline
\end{tabular}

Source: SMK N 1 Bengkulu City in academic year $2017 / 2018$

There was one type of the instruments in this research. It is a reading test.

\section{Reading Test}

Reading test was a primary data of this research to answer the hypothesis. The researcher arranged 50 items of the test taken from several sources. They wereinternet, Buku Bahasa dan Sastra Inggris for Students SMA/SMK Grade $X$, Buku Bahasa Inggris Wajib for SMAMA/SMK Grade $X$, and Buku PR Bahasa Inggris Mata Pelajaran Wajib for SMA/MA/SMK/MAK Grade $X$.

a. The test

There were some questions on the test which were made by constructing from a grid for the instrument test.

b. Instrument Development

Try-out test was conducted to ensure the validity and reability of the instrument, before the study started. There were 50 items of the test that were collected by the researcher from some sources. 
There were some steps for the try out:

1) Content Validity

The content of the test was validated by Mrs. Sri Noflesti as the teacher in SMKN 1 Bengkulu City.

2) Field Validity and Reliability

After the test was validated by expert, the researcher used 50 items test of reading comprehension to the class. It was used to find out the validity and reability.

a) Validity

Heaton (1998) defines the validity as extent to which the test measures what it is supposed. In order to measure the instrument field validity, the researcher sought to find out the item characteristics, by using the following formula:

$$
\begin{aligned}
& \text { F.V }=\frac{C U+C L}{2 . n} \\
& \text { D. } \mathrm{i}=\frac{C U-C L}{n}
\end{aligned}
$$

Note :

FV = Facility Value

DI = Discrimination Index

CU = The total Correct answer

of Upper Half group

$\mathrm{CL}=$ The total Correct answer of Lower Half group

$\mathrm{N} \quad=$ number of sample in one

group

The test is valid if the Facility Value (FV) is between 0.3 and 0.7 and Discrimination Index (DI) score is to be equal 0.3 or more than 0.3 . The score of 30 students toward 40 items reading comprehension test was used to find out the validity. b) Reliability

Gay (1990) stated that to know reliability of the past items, an analysis of KR-21 will be performed as follow:

Note :

$$
\mathrm{R} \text { total }=\frac{(K)(\mathrm{SD}) 2-X(K-X)}{(\mathrm{SD}) 2(\mathrm{~K}-1)}
$$

$\mathrm{K}=$ the number of

items in the test

$\mathrm{SD}^{2}=$ the standard

deviation of the score

$X=$ the mean of the

score

The researcher used reading test as primary data to answer the research questions. The instrument of collecting the data for testing hypothesis consisted of:

1) Instrument development

a) Prepared the instrument

b) Expert validity the instrument

c) Field validity the instrument

2) Pre test and analysis

In pre test analysis the researcher gave test to students in experiment class and control class before treatment. After that the researcher analyze student's score before treatment by using normality, homogenity and independent sample t-test.

3) Treatment

There was one kind of treatment that was in this research. It was metacognitive strategy.

a. The Experimental Group

The researcher applied this strategy to enhance student's reading comprehension.There were several steps in applying the strategynamely: 
- Planning.In this step, the teacher asks the students to plan what they have to do, the materials and sources that they use in the learning process, what kind of strategy that they apply in the class by giving them the journal. See the appendix.

- Monitoring.In this step, the teacher will give students worksheet. It used to know how far the students conprehend the materials that the teacher gives. After that, the students also fill their journal to know their progress in learning process by using this strategy.

- Evaluating.In this step, the students evaluate their knowledge by checking the answer of the worksheet student and find out which answers are true or false. Then, they fill their journal and make a conclusion about the material that they have learned.

b. The Control Group

The researcher applied the model of teaching that the teacher in this class used:

- Observing.In this step, teacher gives the examples and the students observe it.

- Questioning.In this step teacher asks the students about the examples and anything that the students want to know.

- Exploring.In this step, the students identify the examples.

- Associating.In this step, the students analyze, share and compare the example with their partners.
- Communicating.In this step, the students show their result of the study to teacher. It can be act of asking question, writing and answering the question that the teacher gives.

4) Post test analysis

After the strategy was applied in treatment to students in experiment class, the researcher gave post test to the students in experiment class and control class. Thus, the student's score of post test in experiment class and control class were analyzed in terms of normality, homogenity and independent sample t-test by using SPSS.

In analyzing the data, pre-test and post test of the students score were collected and calculated to find out the average and the total score, standard deviation and $t$-calculation. For pre-test data, the researcher found out the average score of students for each class. Parametric statistic was used to find both mean comparative hypothesis if the data form of interval or ratio call as t-test. Independent sample t-test was used to find out the effectiveness of the strategy.

In independent sample t-test, the researcher must find normality and homogenity before analyzing the data of pre-test and post-test by using the formula of t-test.

1. Normality Test

This test compares a set of data on a sample of normal data distribution range of the mean and standard deviation.

2. Follow up

A) If data distribution is normal, parametric test is used. In this case. The data as follows

1) Homogenity is performed 
2) T-test is performed:

a) If data are homogenous, t-test formula a is used.

b) If data are not homogeneous, t-test formula $b$ is used.

B) If data distribution is not normal, non-parametric test is used.

The test. There are two test are used to :

1) Wilcoxon signed ranks test for paired sample test.

2) Mann whitney test for independent sample test.

a. $T$ table was found for two tailed test with $\alpha=0.05 / 5 \%$

b. $T$ count was compared with $t_{\text {table }}$

c. Possibilities

i. $\quad T_{\text {count }} \geq t_{\text {table }}$ (SPSS: sig $P \leq 0.05$; in this case $H_{0}$ is rejected while $H_{a}$ is accepted.

ii. $\quad T_{\text {count }}<t$ table (SPSS: sig $P>0.05$; in this case $H_{0}$ is accepted while $H_{a}$ is rejected.

\section{RESULT AND DISCUSSION}

The process in the classroom is when the researcher applied the strategies in the class to see the effect of student's reading comprehension.

The researcher applied metacognitive strategy to find out the effect of student's reading comprehension, there were several steps namely: identify "what you know" and "what you do not know", in this step the students identified their knowledge about the topic that the students learn today. Talking about thinking, the students disscussed about a topic with giving them a picture and text.

Keep thinking journal, the students made a note of the results in the identification and disscusion about their ability to answer the question of the topic. Make planning and self regulation, the students should start working to improve their responsibility to plan and regulate their learning by finding the difficulties that they faced when learning the material. Re-reporting the thinking process, the students reviewed the result of their disscussions about the topic. Selfevaluation, the students asked to review the material that they do not understand.

The researcher applied conventional strategy for control class. There were several steps namely: "identifying", in this step the students identified the pictures of famous person. "Asking", the student asked about they wanted to know. "Collecting the data/information", the students identified the material and found the function of the text, structure of text. "Associating", the students compared the pictures. "Communicating", the students presented their answer about the material that they disscussed with their group.

The researcher prepared try out instrument for the students before giving the treatment. Try out instrument must be prepared before the researcher gave treatment in class. There were 50 questions prepared which were about reading comprehension. Then, it was tested to students outside experiment class. There were only 30 questions which had facility value between 0.3 and 0.7 and also discrimination index score equal 0.3 or more than 0.3. Therefore, the number of questions above became the valid questions which were used as the instrument for pre-test and post-test. There were 30 questions for pre-test and post-test.

After examining the validity of research instrument by using KR-21, the reability test result in appendix revealed that $R_{\text {total }}$ was 0,895 with the number of question was 25 items. It means that the 
research instrument was reliable with reliability almost 1.00 . So, the instrument can be used as pre-test and post test instruments.

After trying out the instrument, the researcher conducted the research and gave the pre-test to the students. However, the normality of the students pre-test result must be known in order to decide whether the sample was normal or not.Control group has sig.values 0.006, while experiment group has sig.values 0.004 because those groups were distributed abnormally. The significance value of control and experiment group was $>0.05$.Control group has significance value of 0.000 , while experiment group has significance value of 0.001 because those groups were distributed abnormally. Significance value of control and experiment group was $>0.05$. As the data was not normally distributed, nonparametric test was used.

The experiment class used metacognitive strategy and the control class used conventional strategy. before treatment, the researcher gave the pretest for the experiment and control class. From analysis Mann-Whitney test, the researcher found that the average of the pre-test result was 78.10 and 77.58 and the Asymp. Sig (2-tailed) was $0.593<0.05$, so $\mathrm{H}_{0}$ is rejected. It mean there was no significant difference between the experiment and control class in pre-test result.

After knowing the pre-test result the learning process did by using metacognitive strategy for experiment class and using conventional strategy for control class. The average score for the experiment class higher than the control class $85.55>78.43$ and the Asymp. Sig (2tailed) was $0.000<0.05$, so $\mathrm{H}_{0}$ is accepted. It mean there was significant difference between the experiment and control class in post-test result.
After knowing the Mann-Whitney test resukt, the researcher analyzed the differences of pre-test and post-test result in the experiment and control class by using the Wilcoxon test. The average of post-test result higher than pre-test result in the experiment class. It was 78.10 and 85.55 and the Asymp. Sig (2-tailed) was 0.000 lower than 0.05 , so $\mathrm{Ha}$ was accepted. It mean there was significant difference pre-test and post-test result in the experiment class.

Then, the researcher analyzed the differences of pre-test and post-test result in the control class. The average score of post-test result higher than pre-test result in the control class. It was 77.58 and 78.43 and the Asymp. Sig (2-tailed) was 0.241 higher than 0.05 , so $\mathrm{Ha}$ was rejected. It mean there was no significant difference pre-test and post-test in the control class.

As previously mentioned, the main purpose of this research was to know the effect of using metacognitive strategy towards student's reading comprehension at SMK N 1 Bengkulu City Grade X TKI. The learning process happened during fourth meeting for the experiment class and control class. The researcher gave the treatment for the experiment class by using Metacognitive strategy.

For the first meeting, the students still confused what they have to do in the classroom. They did not ever plan what they needed and what they knew before they learned. From these situation the researcher assumed the reason why the students still confused and they did not plan their learning because they did not aware about the important of English material in the classroom. Through, the metacognitive strategy the researcher applied this strategy to improve the awareness of students in the learning process. The researcher guided to plan and think about what they have to do. 
For the second meeting, the students did not bring the sources. However, this step was the part of step in the metacognitive strategy. The metacognitive strategy could not success only one meeting because the metacognitive strategy needed the process to achieve the goal of the learning process. Therefore, there were some of the students that did not apply this strategy perfectly. The researcher told them that preparing the sources was very useful to answer the task that the teacher gave for them.

For the third and fourth meeting, the students in the experiment class applied the steps better than previously. From the first until the fourth meeting, the students applied this strategy perfectly, so there are the improvement result before and after using the metacognitive strategy. It also seemed by their pre-test and post-test result that there were improvements in the experiment class.

The result of this study developed with the result some previous studies. Firstly, Hidayat (2015) with the title "The Correlation of using metacognitive strategy by reading and listening ability student class VII Mts Al-Amiriyyah, Banyuwangi". He found that there was a positive correlation between metacognitive strategy and reading ability in class VII students of Junior High School.

Secondly, Tavakoli (2014) in his research entitled "The Effectiveness of metacognitive strategy awareness in reading comprehension: The case of Iranian University EFL Students" showed that there was a strong positive correlation between reported metacognitive awareness of reading strategies and reading comprehension achievement.
Rastegar et.al (2017) with their title research "The Relationship between MetacognitiveReading Strategies Use and Reading Comprehension Achievement of EFL Learners " revealed that there was a significant positie relationship between the use of overall metacognitive reading strategies by the participants and their reading comprehension achievement.

On the third previous study, the previous researchersfound the relationship between metacognitive strategy and student's reading comprehension in some grades and learning groups. The result was there was positive relationship between metacognitive strategy and student's reading comprehension. This strategy has the good relationship towards reading comprehension in Junior High School students and Efl Learners. The difference between the previous research and this research is the researcher found the effect of two variables and tried this strategy to the vocational school students. In conclusion, metacognitive strategy was effective in student's reading comprehension especially for students in Vocational School. Although, the teacher can used this strategy in their learning process. That is way for another researcher to try this strategy for Senior High School students. This research was done to vocational school students who generally had low to average English ability. If it is done on students with average to high English ability, the result may be different.

\section{CONCLUSIONS}

From analysis of Wilcoxon Test there was significant difference between pre-test and post-test for Experiment Class. Meanwhile, there was no significant difference between pre-test and post-test for Control Class. From analysis of MannWhitney Test, the researcher found that 
there was no significant difference between Experiment and Control Class in pre-test result. Whereas, there was significant difference between Experiment and Control Class in post-test result. Because of the experiment class has differences in pre-test and post-test result and there was differences between the experiment and control class in post-test result. From the result of the research, it can be concluded that this metacognitive strategy has the good effect towards student's reading comprehension.

Based on the description above, it can be concluded that learning using metacognitive learning strategies can improve learning activites. This is because in learning process the students plannedtheir activities, monitored every step of their learningactivites and judged or evaluated the learning outcomes. Where real the success of students in school, mostly lies in its ability learn independently, and monitor their own learning learning by using metacognitive learning strategies provides a positive influence on student's reading comprehension.

\section{REFERENCES}

Creswell, J.W. 2012. Educational Research Planning, Conducting, and Evaluating Quantitative and Qualitative Research. New Jersey: Pearson Prentice Hall Third edition.

Hamra \& Syatriana. 2010. Developing a model teaching reading comprehension for efl students. Teflin Journal.

Hidayat, Ahmad. 2015. The Correlation of using metacognitive strategy with the ability of listening and reading at students class VII MTS Al-Amiriyyah
Blokagung Banyuwangi.Nosi journal vol.2.

Kothari, C.R. 2004. Research methodology: Method and techniques. New Delhi, India: New age International Publisher.

Nunan, D. 1992. Research method in language learning. New York: Cambridge University Press.

Rastegar, et.al. 2017. The Relationship between metacognitive reading strategy use and reading comprehension achievement of EFL learners. OJML journal.

Richard, Jack C.; Schmidt, Richard. 2002. Longman Dictionary of : Language Teaching and Applied Linguistics. (4th.ed.). Londons, UK: Pearson Education.

Sugiyono. 2016. MetodePenelitianPendidikanPendek atanKuantitatif, Kualitatif, dan $R \& D$. Bandung, Indonesia: Alfabeta.

Sutarji. 2016. Keterampilan membaca dan menulis. Kompasiana

Tavakoli. 2014. The effectiveness of metacognitive strategy awareness in reading comprehension: The case of Iranian University EFL students.The reading matrix vol.14. 